\title{
Ibu dan perekonomian keluarga: Karakteristik ibu rumah tangga dalam meningkatkan pendapatan keluarga
}

\author{
Halimatus Sa'diyah, Sukamto, I Nyoman Ruja* \\ Universitas Negeri Malang, Jl. Semarang No. 5 Malang, Jawa Timur, Indonesia \\ *Penulis korespondensi, Surel: nyoman.ruja.fis@um.ac.id
}

Paper received: 03-01-2021; revised: 15-01-2021; accepted: 30-01-2021

\begin{abstract}
Based on village government data, there were 1,818 IRTs in Sukoanyar Village, Pakis District, Malang Regency. Some housewives also work outside the home. Needing a factory is one of the jobs that is mostly occupied by housewives in rural areas. Likewise with the village of Sukoanyar. The number of IRT in Sukoanyar Village who became factory workers was 189 people. Being a factory worker is common for unmarried women, but it can create multiple roles for those who are married. However, what is unique about Sukoanyar Village is that there are housewives who work as factory workers while also pursuing entrepreneurship. This dual role certainly creates problems for women in maintaining the stability of their roles. These problems can come from time management, finance, or other things. Therefore, the focus of the problem to be reviewed is related to the characteristics of IRTs who work as factory workers and entrepreneurs. This research uses a qualitative approach with the type of case study research. The results showed that housewives who work in factories and are entrepreneurial are generally still in their productive age, but have a low level of education. The family's financial condition is quite stable because their needs can be fulfilled properly. In dividing time and finances, always apply a priority scale, besides that there is also a good relationship between family members to help each other complete homework.
\end{abstract}

Keywords: housewife; factory workers; entrepreneur

\begin{abstract}
Abstrak
Berdasarkan data pemerintah desa, terdapat 1.818 orang IRT di Desa Sukoanyar Kecamatan Pakis Kabupaten Malang. Beberapa ibu rumah tangga juga bekerja di luar rumah. Butuh pabrik merupakan salah satu kerja yang banya ditekuni oleh Ibu rumah tangga di pedesaan. Begitu pula dengan desa Sukoanyar. Jumlah IRT di Desa Sukoanyar yang menjadi buruh pabrik sebanyak 189 orang. Menjadi buruh pabrik adalah hal biasa bagi wanita yang belum menikah, tetapi dapat menimbulkan peran ganda bagi yang sudah menikah. Namun, uniknya di Desa Sukoanyar terdapat ibu rumah tangga yang bekerja sebagai buruh pabrik sekaligus menekuni dunia wirausaha. Peran ganda tersebut tentunya menimbulkan masalah bagi wanita dalam menjaga kestabilan perannya. Permasalahan tersebut bisa berasal dari manajemen waktu, keuangan, maupun hal lainnya. Oleh karena itu fokus masalah yang akan diulas terkait karakteristik IRT yang bekerja sebagai buruh pabrik dan wirausaha. Penelitian ini menggunakan pendekatan kualitatif dengan jenis penelitian studi kasus. Hasil penelitian menunjukkab bahwa Ibu rumah tangga yang bekerja di pabrik dan berwirausaha pada umumnya masih berada dalam usia produktif, namun memiliki tingkat pendidikan rendah. Kondisi keuangan keluarga cukup stabil karena kebutuhan dapat tercukupi dengan baik. Dalam membagi waktu dan keuangan selalu menerapkan skala prioritas, selain itu juga terdapat hubungan yang baik antar anggota keluarga untuk saling menolong menyelesaikan pekerjaan rumah.
\end{abstract}

Kata kunci: ibu rumah tangga; buruh pabrik; wirausaha

\section{Pendahuluan}

Laki-laki yang telah berkeluarga tentu mempunyai kewajiban untuk mencari uang untuk mencukupi kebutuhan keluarganya. Masalah yang terjadi adalah harga untuk pemenuhan sandang, pangan, dan papan semakin mahal sehingga kemudian menimbulkan ketimpangan 
antara pemasukan dengan pengeluaran keluarga. Hal ini dapat menimbulkan masalah keuangan bagi masyarakat kelas sosial menengah ke bawah. Permasalahan tersebut merupakan akar dari tumbuhnya kemiskinan. Solusi yang kemudian diterapkan, istri terpaksa mencari pekerjaan agar dapat membantu suami menghasilkan uang. Apapun pekerjaan dilakukan asalkan halal dan mendapatkan uang tambahan termasuk menjadi buruh pabrik. Tantangan pokok yang demikian pada intinya adalah rendahnya tingkat kemakmuran dan kesejahteraan penduduk pedesaan sebagaimana tercermin dari kekurangan pangan dan gizi, kesehatan, lingkungan yang kurang memadahi, pendidikan dan ketrampilan yang rendah. Indikator-indikator tersebut menjadi permasalahan pokok yang harus ditanggulangi (Mubyarto, 1985).

Wanita yang memilih untuk bekerja di pabrik memiliki tanggung jawab untuk menjadi seorang istri dan ibu, serta berperan ganda membantu suami mencari nafkah bagi keluarga. Peran ganda yang dijalani wanita pada saat ini sebagai ibu rumah tangga dan buruh pabrik memang menyebabkan berbagai dampak positif dan negatif. Dampak positifnya adalah pendapatan keluarga bertambah sedangkan dampak negatifnya adalah waktu untuk memberikan kasih sayang kepada keluarga terutama anak menjadi berkurang. Meskipun mereka menyadari akan dampak-dampak yang ditimbulkan mereka tetap konsisten dengan peran ganda yang dijalani. Tidak cukup dengan menjadi buruh pabrik ada juga wanita yang kemudian menekuni dunia wirausaha untuk menambah penghasilannya. Hal ini wajar karena yang paling sering dipikirkan orang dari sebuah keluarga adalah jalan keluar dari alternatif ketika membuat keputusan ekonomi. Masalah ekonomi tentunya terjadi pada setiap keluarga dan untuk mengatasinya tentu anggota keluarga harus saling bekerja sama dalam mengumpulkan pendapatan. Misalnya saja seorang ibu rumah tangga yang seharusnya dirumah akan memilih untuk bekerja membantu suami mendapatkan pendapatan yang lebih untuk mencukupi kebutuhan yang semakin hari lebih beragam. Berdasarkan pilihan ibu rumah tangga tersebut tentu ada pilihan yang dikorbankan yakni antara mendapat penghasilan dan kurangnya waktu dalam mengurusi rumah tangga (Doriza, 2015). Peran yang kompleks tersebut tidak terjadi pada setiap orang, akan tetapi peneliti menemukan keunikan tersebut pada beberapa orang yang tinggal di Desa Sukoanyar yang terletak di Kecamatan Pakis Kabupaten Malang. Berdasarkan pengamatan peneliti menemukan beberapa orang ibu rumah tangga yang bekerja di pabrik namun juga memiliki kegemaran berwirausaha.

Berdasarkan latar belakang di atas, rumusan masalah pada artikel ini adalah tentang karakteristik ibu rumah tangga yang bekerja sebagai buruh pabrik dan berwirausaha. Karakteristik tersebut berupa umur, tingkat pendidikan, gaya hidup, manajemen waktu, jumlah beban keluarga, serta alasan memilih berwirausaha disamping bekerja di pabrik.

\section{Metode}

Penelitian ini menerapkan metode penelitian kualitatif dengan desain studi kasus. Adapun kualitatif dipilih karena mampu untuk mengungkapkan kondisi objek secara kulitas dan ilmiah. Pengumpulan data dilakukan dengan mentriangulasikan teknik observasi, wawancara, dan dokumentasi. Data diperoleh dari informan kunci dan pendukung. Informan pendukung dalam penelitian ini adalah suami (Pak Nur, Pak Solihin, Pak Susilo, Pak Arifin), dan anak (Puspita) dari informan kunci. Sementara itu, informan kunci dalam penelitian ini adalah ibu rumah tangga yang bekerja di pabrik dan memiliki usaha diantaranya adalah $\mathrm{Bu}$ Win, $\mathrm{Bu}$ Nur, Bu Ninik, Bu Yuliati, dan Bu Eni. Data sekunder sebagai data pendukung dalam penelitian ini adalah dokumen pemerintah desa terkait profil dan data kependudukan. Analisis data yang 
dilakukan bersifat induktif menggunakan model interaktif Miles dan Huberman yang terdiri atas pengumpulan data, reduksi data, penyajian data dan penarikan kesimpulan (Miles \& Huberman, 2002). Adapun hasil analisis data lebih menekankan makna daripada generalisasi (Sugiyono, 2016). Lokasi penelitian ini di Desa Sukoanyar Kecamatan Pakis Kabupaten Malang.

\section{Hasil dan Pembahasan}

Ibu rumah tangga adalah status sosial yang diberikan kepada seorang wanita yang sudah menikah dan memiliki anak. Sebagai seorang ibu rumah tangga tentunya memiliki kewajiban untuk tetap merawat anak, melayani suami, dan mengurus rumah. Tetapi jaman sekarang banyak ibu rumah tangga yang tidak hanya fokus pada kewajiban di rumah, tetapi juga mengambil peran membantu suami dalam mencari nafkah. Banyak faktor yang menjadi latar belakang ibu rumah tangga tetap memilih bekerja. Adapun alasan utama adalah untuk membantu perekonomian keluarga dan untuk mengisi waktu luang agar tidak merasa bosan di rumah. Kemampuan manusia untuk bekerja merupakan keahlian khusus yang membedakan antara manusia dengan hewan seperti yang di utarakan oleh Marx. Menurut Marx yang membuat manusia berbeda dengan mahluk lain karena manusia dapat bekerja. Melalui bekerja manusia menjadi produsen dengan demikian produk dari hasil bekerja merupakan hakikat manusia yang menjadi pembeda dengan mahluk lain seperti binatang (Damsar, 2012). Meskipun demikian seorang ibu rumah tangga juga tidak bisa meninggalkan kewajibannya merawat anak, melayani suami, dan mengurus rumah (Wijayanti, 2010).

Banyak pekerjaan yang dapat ditekuni oleh ibu rumah tangga ketika berada di luar rumah salah satunya adalah menjadi buruh pabrik. Menjadi buruh pabrik merupakan solusi tepat bagi warga desa yang ingin bekerja tetapi modal pendidikan yang dimiliki cukup rendah. Bekerja di pabrik tidak membutuhkan ijazah tinggi pada jaman dahulu hanya dibutuhkan keuletan untuk mempelajari pekerjaannya saja agar dapat menghasilkan produk bagi pabrik. Seluruh informan menuturkan bahwa dengan ijazah Sekolah Dasar tidak banyak pekerjaan yang dapat dipilih sehingga kemudian memutuskan untuk bekerja di pabrik. Seperti yang dikemukakan oleh Nurhardjo (2012) bahwa meskipun tingkat pe ndidikan buruh relatif rendah namun hal tersebut tidak menjadi masalah bagi perusahaan karena kualifikasi yang diperlukan untuk melakukan pekerjaan umumnya tidak diperoleh dari pendidikan formal melainkan dari ketrampilan individu yang dapat dipelajari sendiri, pengalaman bekerja, maupun pelatihan yang diberikan oleh pihak perusahaan.

Mempelajari pekerjaan yang menjadi tanggung jawab buruh ketika di pabrik bukan hal yang sulit karena umur informan masih dalam kategori usia produktif. Usia produktif berkisar pada rentang 15-64 tahun. Pada usia produktif manusia dianggap mampu bekerja secara kreatif, efektif, dan efisien untuk menghasilkan sesuatu yang berguna bagi kelangsungan hidupnya. Semangat untuk berfikir kreatif dan bertindak secara aktif menjadi salah satu faktor pendorong informan untuk bekerja di pabrik dan menekuni usaha berdagang. Meskipun bekerja pada dua pekerjaan bukan hal yang mudah karena mengorbankan tenaga dan fikiran yang banyak namun pada usia produktif ini semua masih bisa teratasi dengan baik selama masih diberikan kesehatan secara jasmani dan rohani.

Jarak dari rumah menuju tempat kerja masing-masing informan berbeda karena lokasi pabrik mereka juga tidak sama. Jarak tersebut berkisar mulai dari 5,3 km - $13 \mathrm{~km}$. Namun keseluruhan jarak bisa di tempuh dengan waktu maksimal 30 menit. Kendaraan yang digunakan juga cukup menggunakan angkutan umum. Lokasi Desa Sukoanyar yang berada 
pada jalur utama menuju kota membuat masyarakat tidak kesulitan dalam mencari kendaraan umum. Kendaraan umum yang melewati jalur Desa Sukoanyar juga cukup banyak sehingga tidak terlalu lama menunggu angkutan yang lewat. Akses transportasi yang memudahkan aktivitas masyarakat untuk berpindah lokasi merupakan salah satu dampak positif perubahan sosial dalam bidang teknologi. Soekanto (2012) berpendapat bahwa faktor-faktor penyebab perubahan sosial ada yang bersumber dari dalam masyarakat ada pula faktor yang dari luar masyarakat. Faktor yang bersumber dari dalam masyarakat salah satunya adalah adanya penemuan-penemuan baru. Penemuan baru tersebut salah satunya adalah penemuan dalam bidang teknologi berupa mobil atau sepeda motor untuk alat transportasi. Seorang informan memilih untuk menggunakan sepeda motor ketika ke pabrik dikarenakan harus menitipkan anaknya terlebih dahulu kepada mertuanya yang berbeda desa sehingga akan kesulitan jika harus naik angkutan umum. Pilihan untuk menggunakan sepeda motor pribadi tersebut merupakan salah satu kebutuhan bukan semata-mata untuk gaya hidup agar terlihat memiliki ekonomi berlebih.

Gaya hidup ibu rumah tangga yang bekerja di pabrik dan sekaligus berwirausaha dapat dikatakan biasa saja dan tidak mencerminkan ciri-ciri masyarakat yang hedon. Hedon adalah paham yang memandang tujuan utama hidup manusia adalah mencari kesenangan bersifat duniawi. Hal ini didasarkan pada anggapan bahwa semua orang cenderung menghindari halhal yang menyulitkan dan melakukan perbuatan yang mendatangkan kesenangan (Shaleh, 2004). Fakta yang ada, uang yang diperoleh dari suami dan hasil bekerja maupun berjualan digunakan untuk memenuhi kebutuhan pokok utamanya persediaan sembako guna mencukupi makanan sehari-hari, kemudian selebihnya dikeluarkan sesuai kebutuhan saja. Berdasarkan observasi dan wawancara diketahui bahwa kesibukan ibu rumah tangga yang bekerja di pabrik dapat digolongkan tinggi. Mulai dari bangun tidur harus segera bersiap bekerja dan setelah pulang dari pabrik harus mengerjakan pekerjaan rumah dan segera istirahat sehingga tidak punya waktu untuk hidup berfoya-foya. Terlebih lagi dengan kondisi mereka yang memiliki barang dagangan maka bertambah pula kesibukannya. Ketika hari libur datang mereka lebih memilih untuk beristirahat di rumah dan mengurus dagangannya penuh dibandingkan harus berlibur atau sekedar jalan-jalan di mall.

Memiliki aktivitas yang padat sebagai buruh pabrik dan wirausaha tidak membuat mereka mengasingkan diri dari kegiatan masyarakat sekitar. Mereka tetap aktif bersosialisasi dengan mengikuti berbagai kegiatan yang ada dilingkungan tempat tinggalnya. Kebanyakan kegiatan tersebut bersifat religi berupa kelompok tahlil maupun istighosah. Kegiatan semacam ini dilakukan pada malam hari sesuai kesepakatan dan bertempat di rumah anggota kelompoknya sesuai dengan urutan. Aktivitas yang dilakukan adalah membaca bacaan tahlil, yasin, maupun istighosah secara bersama-sama. Tidak hanya membaca doa-doa saja, kegiatan semacam ini juga dilengkapi dengan arisan antar anggota kelompok. Sebagai umat islam yang taat pada ajaran agama, menambah pahala merupakan motivasi yang utama mengikuti kegiatan semacam ini. Motivasi adalah daya penggerak untuk membangkitkan aktivitas makhluk hidup yang menimbulkan tingkah laku serta mengarahkannya pada tujuan tertentu (Shaleh, 2004). Sesuai dengan pernyataan tersebut kekuatan penggerak untuk mengikuti kegiatan sosial dalam bidang religi selain menyambung tali silaturahmi adalah mencari pahala dengan tujuan agar selamat di dunia dan akhirat.

Berdasarkan uraian di atas peneliti juga menganalisis kembali dengan penelitian terdahulu yang ditulis oleh Hapsari (2013) yang menemukan ditemukan bahwa latar belakang 
seorang wanita bekerja sebagai buruh adalah untuk membantu perekonomian keluarga. Selain itu tingkat pendidikan yang rendah juga menjadi alasan banyak wanita untuk menjadi buruh, karena mereka kesulitan apabila harus memilih pekerjaan lain yang tidak sesuai dengan kualifikasi mereka. Ijin dari anggota keluarga, termasuk suami juga menjadi faktor pendorong mereka untuk bekerja sebagai buruh hingga saat ini. Hasil penelitian tersebut sesuai dengan yang peneliti temukan di Desa Sukoanyar terkait ibu rumah tangga yang bekerja di pabrik dan memiliki unit usaha. Informan yang peneliti temukan di Desa Sukoanyar juga memiliki motivasi untuk menambah pendapatan keluarga. Begitu pula dengan latar belakang pendidikan, para buruh juga memiliki tingkat pendidikan rendah sehingga mereka mau menjalani pekerjaan sebagai buruh di pabrik. Terkait dengan ijin oleh anggota keluarga juga sama, informan mendapat persetujuan dari anggota keluarganya untuk bekerja sebagai buruh.

Ibu rumah tangga yang bekerja di pabrik dan memiliki usaha rata-rata memiliki seorang suami dan dua orang anak. Dengan kondisi suami yang bekerja tentunya kondisi perekonomian keluarga tidak terlalu buruk ditambah lagi dengan bantuan dari istri yang bekerja di pabrik. Uang dari hasil suami bekerja dan hasil ibu rumah tangga yang bekerja di pabrik pada dasarnya sudah cukup untuk memenuhi kebutuhan sehari-hari. Hal ini sesuai dengan hasil wawancara bahwa kebutuhan pokok mereka terpenuhi dengan baik dan kebutuhan lainnya juga dapat dipenuhi berdasarkan skala prioritas. Berdasarkan penjelasan tersebut dapat diketahui bahwa bekerja dan menerima pendapatan mampu menunjang kelangsungan hidup manusia. Seperti yang dijelaskan oleh Sajogyo (1985) yakni peluang berusaha dan peluang bekerja merupakan dua jalur pembuka dari satu mata rantai yang menentukan jalur pendapatan, tingkat pangan, sandang, perumahan, serta tingkat pendidikan dan kesehatan yang pelayanannya terjangkau.

Bekerja di pabrik tentu saja membuat seseorang bertemu lebih banyak orang apabila dibandingkan dengan ibu rumah tangga yang hanya di rumah saja. Pergaulan yang semakin luas tersebut akhirnya membuat komunikasi antar teman yang semakin banyak. Dikenal dengan pribadi yang mudah bergaul membuat mereka dipercayai untuk menjualkan barang dagangan yang dimiliki oleh temannya. Hal ini membuktikan temuan Zaki (2013) bahwa seorang yang berjiwa entrepreneurship adalah seseorang yang aktif dan juga memiliki kepercayaan diri yang tinggi. Alasan ini yang kemudian menjadi latar belakang seorang ibu rumah tangga yang sudah bekerja di pabrik memulai usahanya. Kerjasama yang terjadi tersebut tentunya didasari atas perjanjian bagi hasil. Keputusan tersebut juga di dasari dengan tujuan untuk membantu teman dengan kelebihan mendapat keuntungan secara materiil. Hal tersebut juga sesuai dengan teori pilihan rasional yang menjelaskan bahwa tindakan seseorang tentunya didasari oleh pemikiran logis (Coleman, 2008).

\section{Simpulan}

Sukoanyar merupakan Desa yang terletak di Kecamatan Pakis Kabupaten Malang. Masyarakat Desa Sukoanyar memiliki mata pencaharian yang beragam. Salah satu pekerjaan yang ditekuni oleh wanita yang bermukim di Desa Sukoanyar adalah sebagai buruh pabrik. Karakteristik wanita yang bekerja sebagai buruh pabrik adalah memiliki tingkat pendidikan rendah yakni sebatas Sekolah Dasar (SD). Ibu rumah tangga yang bekerja di pabrik ini masih dalam kategori usia produktif yang berkisar antara 15-64 tahun. Jarak dari rumah menuju pabrik cukup beragam, namun keseluruhan dapat ditempuh dengan waktu maksimal 30 menit. Untuk menuju pabrik mereka menggunakan angkutan umum, ada pula yang mengendarai sepeda motor pribadi, karena harus menitipkan anaknya terlebih dahulu di rumah mertua 
sehingga kesulitan jika naik angkutan umum. Uang yang diperoleh dari upah bekerja dan pemberian suami digunakan memenuhi kebutuhan pokok dan sisanya untuk pengeluaran sesuai kebutuhan. Tidak hanya tekun bekerja mereka juga aktif dalam bersosialisasi dalam perkumpulan tahlil maupun sejenisnya yang berkaitan dengan kegiatan religi. Kebiasaan menjadi orang yang aktif dalam bekerja dan bersosialisasi membuat mereka dipandang sebagai kepribadian yang ramah dan memiliki kepercayaan diri tinggi. Kenyataan yang demikian akhirnya membuat mereka mendapat tawaran kerjasama dalam hal berdagang oleh teman yang bekerja di pabrik yang sama.

Saran peneliti bagi Pemerintah Desa Sukoanyar adalah dikembangkannya sektor wirausaha untuk tidak hanya menjadi re-seller tetapi juga dapat menjadi produsen. Bagi informan supaya lebih mempelajari lagi cara pengelolaan uang yang baik berdasarkan sumber dan kebutuhannya masing-masing sehingga memudahkan untuk mengontrol perkembangan usaha dagang yang dimiliki. Saran bagi prodi pendidikan IPS hendaknya menjadikan hasil penelitian ini sebagai materi perkuliahan kepada mahasiswa dan sebagai referensi ilmiah yang berkaitan dengan dinamika kependudukan. Bagi Sekolah Lanjutan Tingkat Pertama (SLTP/ SMP/ MTs), hendaknya menjadikan hasil penelitian ini sebagai bahan ajar kepada siswa mengenai dinamika kependudukan. Untuk peneliti selanjutnya dapat mengkaji mengenai dampak yang timbul pada anak terkait peran ibu rumah tangga yang bekerja di pabrik dan memiliki usaha.

\section{Daftar Rujukan}

Coleman, J. S. (2008). Dasar-dasar teori sosial. Nusamedia.

Damsar. (2012). Pengantar sosiologi pendidikan. Prenadamedia Group.

Doriza, S. (2015). Ekonomi Keluarga. PT Remaja Rosdakarya. https://www.mendeley.com/catalogue/f660cda1-3aad-31d6-adfffd101447c894/?utm_source=desktop\&utm_medium=1.19.8\&utm_campaign=open_catalog\&userDocu mentId=\%7Bf5ee60c2-5763-41ca-9961-e6c3bf24a004\%7D

Hapsari, E. C. (2013). Perempuan buruh gendong di pasar tradisional (Studi kasus di Pasar Bandungan Kecamatan Bandungan Kabupaten Semarang).

Miles, M., \& Huberman. (2002). Analisis Data Kualitatif. UI Press.

Mubyarto. (1985). Peluang Kerja dan Berusaha di Pedesaan. BPFE.

Nurhardjo, B. (2012). Karakteristik dan kinerja buruh wanita pada gudang tembakau GMIT di Kecamatan Panti Kabupaten Jember. Jurnal Bisnis Dan Manajemen, 6(1), 55-68. https://jurnal.unej.ac.id/index.php/BISMA/article/view/50/27

Sajogyo, P. (1985). Peranan Wanita dalam Pembangunan Masyarakat Desa. CV Rajawali.

Shaleh, A. R. (2004). Psikologi suatu pengantar dalam perspektif Islam. Kencana.

Soekanto, S. (2012). Sosiologi suatu pengantar. PT Raja Grafindo Persada.

Sugiyono. (2016). Metode penelitian kuantitatif, kualitatif, dan R\&D. Alfabeta Bandung.

Wijayanti, D. M. (2010). Belenggu kemiskinan buruh perempuan pabrik rokok. Jurnal Komunitas, 2(2), 84-93. http://journal.unnes.ac.id/nju/index.php/komunitas/article/view/2278/2330 